\title{
PROSPEK PENGEMBANGAN PARIWISATA DANAU MATANO DALAM MENINGKATKAN PENDAPATAN ASLI DAERAH (PAD) KABUPATEN LUWU TIMUR
}

\author{
I Ketut Patra*1, Tri Nanda Permata Sari Hayat ${ }^{1}$ \\ ${ }^{1}$ Sekolah Tinggi Ilmu Ekonomi Muhammadiyah Palopo \\ *patra@stiem.ac.id
}

\begin{abstract}
This study aims to determine the strategy of prospects for the development of tourism in Lake Matano, East Luwu Regency, South Sulawesi Province. The results of this study are expected to be a reference in the management and development of tourism. Empowering local communities to improve their standard of living. This research was started from March to April 2016. Data collection was carried out by field observation method. The variables observed were physical potential and regional supporting factors. In addition, structured interviews were also conducted using questionnaires to the communities around the research sites and the government to find out their perceptions about the possibility of applying tourism on Lake Matano.
\end{abstract}

Keywords: Tourism Development Strategy

\begin{abstract}
Abstrak
Penelitian ini bertujuan untuk mengetahui strategi prospek pengembangan pariwisata di Danau Matano Kabupaten Luwu Timur Propinsi Sulawesi Selatan. Hasil penelitian ini diharapkan dapat menjadi acuan dalam pengelolaan dan pengembangan pariwisata. Pemberdayaan masyarakat lokal guna meningkatkan taraf hidupnya. Penelitian ini mulai dilakukan mulai dari bulan Maret sampai dengan April 2016. Pengambilan data dilakukan dengan metode observasi lapangan. Variable yang diamati yaitu potensi fisik dan faktor penunjang kawasan. Selain itu juga dilakukan wawancara terstruktur dengan menggunakan kuisioner terhadap masyarakat di sekitar lokasi penelitian dan pemerintah untuk mengetahui persepsi mereka mengenai kemungkinan penerapan pariwisata di Danau Matano
\end{abstract}

Kata Kunci : Strategi Pengembangan Pariwisata

\section{PENDAHULUAN}

Sektor pariwisata sebagai kegiatan perekonomian telah menjadi andalan dan prioritas pengembangan bagi sejumlah Negara, terlebih bagi Negara berkembang seperti Indonesia yang memiliki potensi wilayah yang luas dengan adanya daya tarik wisata cukup besar, banyaknya keindahan alam, aneka warisan sejarah budaya dan kehidupan masyarakat. Dan obyek wisata yang ada di Soroako yaitu Danau Matano merupakan salah satu kekayaan alam yang patut untuk dibanggakan.

Dengan diberlakukannya UU No. 32 Tahun 2004, UU No. 33 Tahun 2004 yang memberikan kewenangan lebih luas pada Pemerintah Daerah untuk mengelola wilayahnya, membawa implikasi semakin besarnya tanggung jawab dan tuntutan untuk menggali dan mengembangkan seluruh potensi sumber daya yang dimiliki daerah dalam rangka menopang perjalanan pembangunan daerah.
Dengan adanya UU tersebut pemerintah memiliki keleluasaan untuk mengembangkan objek wisata.

Kabupaten Luwu Timur khususnya sektor pariwisata merupakan salah satu sektor strategis dan potensial untuk dikelola, dikembangkan dan dipasarkan. Obyek Wisata Danau Matano merupakan obyek wisata favorit yang mempunyai daya tarik tinggi dengan suasana dan pemandangannya yang masih asri. Obyek Wisata Danau Matano memiliki daya tarik dan potensi dalam peningkatan pendapatan daerah yang menjadi salah satu asset wisata alam Kabupaten Luwu Timur.

\section{KAJIAN PUSTAKA}

\section{Pariwisata dan Kepariwisataan}

Pariwisata berkaitan dengan manusia dan masyarakatnya, untuk itu perlu dijelaskan 
mengenai pengertian dari Pariwisata, Kepariwisataan, Wisata dan Wisatawan.

Menurut Yoeti (1991) Pariwisata berasal dari dua kata yakni, Pari dan Wisata. Pari dapat diartikan sebagai banyak, berkali-kali, berputarputar atau lengkap. Sedangkan wisata dapat diartikan sebagai perjalanan atau bepergian yang dalam hal ini sinonim dengan kata travel dalam bahasa Inggris. Atas dasar itu maka kata pariwisata dapat diartikan sebagai perjalanan yang dilakukan berkali-kali atau berputar-putar dari suatu tempat ke tempat yang lain, yang dalam bahasa Inggris disebut tour. Kepariwisataan menurut Undang - undang no. 10 Tahun 2009 adalah keseluruhan kegiatan yang terkait dengan pariwisata dan bersifat multidimensi serta multidisiplin yang muncul sebagai wujud kebutuhan setiap orang dan negara serta interaksi antara wisatawan dan masyarakat setempat, sesama wisatawan, Pemerintah Daerah dan pengusaha.

\section{Wisata dan Wisatawan}

Menurut Undang-undang No.10 Tahun 2009 tentang kepariwisataan, wisata adalah kegiatan perjalanan yang dilakukan oleh seseorang atau sekelompok orang dengan mengunjungi tempat tertentu untuk tujuan rekreasi, pengembangan pribadi, atau mempelajari keunikan daya tarik wisata yang dikunjungi dalam jangka waktu sementara.

Wisata adalah kegiatan perjalanan (travel) yang dilakukan atas (sukarela), bersifat sementara waktu, bertujuan untuk menikmati objek dan daya tarik wisata di suatu daerah.

Menurut Undang-undang No.10 Tahun 2009 pasal 1 tentang kepariwisataan, Wisatawan adalah Orang yang melakukan kegiatan wisata. Jadi menurut pengertian tersebut, semua orang yang melakukan perjalanan wisata dinamakan Wisatawan. Adapun tujuannya yang penting perjalanan itu bukan untuk menetap dan tidak untuk mencari nafkah di tempat yang dikunjungi. Dalam bahasa Ingris wisatawan itu disebut tourist.

\section{Wisata Alam}

Wisata alam adalah bentuk kegiatan rekreasi dan pariwisata yang memanfaatkan potensi sumberdaya alam, baik dalam keadaan alami maupun setelah ada usaha budidaya, sehingga memungkinkan wisatawan memperoleh kesegaran jasmaniah dan rohaniyah, mendapatkan pengetahuan dan pengalaman serta menumbuhkan inspirasi dan cinta terhadap alam (Anonymous, 1982 dalam Saragih, 1993)

Wisata alam merupakan kegiatan rekreasi dan pariwisata yang memanfaatkan potensi alam untuk menikmati keindahan alam baik yang masih alami atau sudah ada usaha bubidaya, agar ada daya tarik wisata ke tempat tersebut. Wisata alam digunakan sebagai penyeimbang hidup setelah melakukan aktivitas yang sangat padat, dan suasana keramean kota. Sehingga dengan melakukan wisata, alam tubuh dan pikiran kita menjadi segar kembali dan bias bekerja dengan lebih kreatif lagi karena dengan wisata alam memungkinkan kita memperoleh kesenangan jasmani dan rohani.

Dalam melakukan wisata alam kita harus melestarikan area yang masih alami, member manfaat secara ekonomi dan mempertahankan keutuhan budaya masyarakat setempat sehingga bisa menjadi Desa wisata, agar desa tersebut memiliki potensi wisata yang dilengkapi dengan fasilitas pendukung seperti alat transportasi atau penginapan.

\section{Stakeholder Ekowisata}

Sektor ekowisata mempertemukan dua atau lebih budaya yang berbeda. Wisatawan memperoleh pengalaman berhaga dari budaya local, sementara penduduk local memainkan proses edukasi perihal lingkungan spesifik local dan mendapatkan penghasilan. Sinergi tersebut harus tetap dipertahankan dengan dukungan kebijakan pemerintah bagi beroperasinya sektor swasta dan bantuan dari kelompok masyarakat. (Nugroho, 2011) 


\section{Daya Tarik Wisata}

Daya tarik wisata sejatinya merupakan kata lain dari obyek wisata namun sesuai peraturan pemerintah Indonesia tahun 2009 kata obyek wisata sudah tidak relevan lagi untuk menyebutkan suatu daerah tujuan wisatawan maka digunakanlah kata "Daya Tarik Wisata" maka untuk mengetahui apa arti dan makna dari daya tarik wisata di bawah ini adalah beberapa definisi mengenai Daya Tarik Wisata menurut beberapa ahli:

Berdasarkan Undang-undang Republik Indonesia No. 10 tahun 2009, Daya Tarik Wisata dijelaskan sebagai salah satu yang memiliki keunikan, keindahan, dan nilai berupa kenaekaragaman kekayaan alam, budaya, hasil buatan manusia yang menjadi sasaran atau kunjungan wisatawan.

Yoeti dalam bukunya "Pengantar Ilmu Pariwisata" tahun 1985 menyatakan bahwa daya tarik wisata atau "tourist attraction", istilah yang lebih sering digunakan, yaitu segala sesuatu yang menjadi daya tarik bagi orang untuk mengunjung suatu daerah tertentu.

Syarat-syarat Objek Wisata atau Daya Tarik Wisata : Sebuah Objek Wisata atau Daya Tarik Wisata yang baik harus dapat mendatangkan wisatwan sebanyak-banyaknya, menahan mereka ditempat atraksi dalam waktu yang cukup lama dan member kepuasan kepada wisatawan yang dating berkunjung. Untuk mencapai hasil itu, beberapa syarat harus dipenuhi,yaitu:

\section{Kawasan Wisata dan Pembangunan Wisata}

Kawasan Wisata adalah sebuah area dengan luas tertentu yang dibangun atau disediakan untuk memenuhi kebutuhan pariwisata. Sedangka Usaha Pariwisata adalah kegiatan yang bertujuanmenyelenggarakan jasa pariwisata, menyediakan objek dan daya tarik, usaha-usaha sarana pariwisata dan usaha-usaha lain yang terkait. Pembangunan Pariwisata merupakan pembangunan sektor-sektor dan komponen-komponen yang terkait langsung maupun tidak langsung dengan industry pariwisata. Menurut Suyitno (2001) komponen wisata terdiri atas sarana transportasi, sarana akomodasi, sarana makan-minum, objek wisata, dan atraksi, sarana hiburan, took cindera mata, dan pramuwisata. Dalam pengembangan pariwisata harus disertai pembangunan dalam bidang-bidang lain karena pariwisata dipandangsebagai system dimana antara aspek satu dan lainnya memiliki ketergantungan.

\section{Pendapatan Asli Daerah (PAD)}

Pendapatan Asli Daerah (PAD) adalah pendapatan yang diperoleh daerah yang dipungut berdasarkan Peraturan Daerah sesuai perundang-undangan. Sampai saat ini yang termasuk Pendapatan Asli Daerah adalah pendapatan yang berasal dari daerah itu sendiri dan dapat di dapatkan melalui pajak daerah, retribusi daerah, BUMD, dan hasil kerjasama dengan pihak ketiga.

Menurut Undang-undang No.32 Tahun 2004, tentang Pemerintah Daerah dan Undangundang No.33 Tahun 2004, tentang perimbangan keuangan antara Pemerintah Pusat dan Pemerintah Daerah, sumner-sumber Pendapatan Asli Daerah (PAD) terdiri dari Hasil Pajak Daerah Pajak daerah adalah pungutan daerah menurut peraturan daerah yang dipergunakan untuk pembiyaan rumah tangga daerah sebagai badan hukum public. Ciri-ciri yang menyertai pajak daerah adalah :

Pajak daerah berasal dari Pajak Negara yang dipisahkan oleh daerah sebagai pajak daerah. Penyerahan pauak daerah dilakukan berdasarkan peraturan daerah. Pajak daerah dipungut oleh daerah berdasarkan kekuatan undang-undang dan peraturan hukum yang berlaku lainnya. Menurut UU No.34 Tahun 2000, retribusi daerah adalah pungutan daerah sebagai pembayaran atas jasa atau pemberi izin tertentu yang khusus disediakan dan atau diberikan oleh Pemerintah Daerah untuk kepentingan orang pribadi atau badan.

\section{METODE}

Penelitian bertempat di Desa Soroako, Kecamatan Nuha, Kabupaten Luwu Timur, Provinsi Sulawesi Selatan. Dengan mengambil 
informasi dari Internet, masyarakat setempat, serta Wisatawan yang berkunjung ke Danau Matano.

Jenis data yang digunakan dalam penelitian ini yaitu data primer dan data sekunder. Dimana pengumpulan data dilakukan dengan menggunakan pendekatan observasi, wawancara, dam studi literature untuk memperoleh data faktor-faktor penghambat dan penunjang dalam pengelolaan pariwisata di Danau Matano. Berdasarkan beberapa aspek yang dikemukakan di atas, data primer diperoleh melalui pengamatan dan pengumpulan data di lapangan.

\section{Populasi dan Sampel}

Populasi dalam penelitian ini adalah seluruh pelaksaan prospek pengembangn pariwisata. Sedangkan sampelnya adalah data pengunjung dari Danau Matano dari tahun 2009 - 2015.

\section{Metode Analisis Data}

Hasil penelitian di lapangan kemudian dievaluasi secara lebih cermat untuk memperoleh kesimpulan yang paling tepat dalam perencanaan pengembangan pariwisata dengan menggunakan metode analisis SWOT (Strength, Weakness, Opportunity, Threat)

Analisis dilakukan mulai dari data mentah yang ada sampai pada hasil penelitian yang dicapai. Dalam penelitian ini langkah-langkah analisis data dilakukan sebagai berikut :

Melakukan pengklasifikasian data, faktor apa saja yang menjadi kekuatan dan kelemahan sebagai faktor internal, peluang, dan ancaman sebagai faktor eksternal. Pengklasifikasian ini akan menghasilkan tabel informasi SWOT.

Melakukan analisis SWOT yaitu membandingkan antara faktor eksternal Peluang (Opportunities) dan Ancaman

\section{Metode Pengumpulan Data}

Penelitian ini tergolong ke dalam jenis penelitian non- eksperimen, dimana pengumpulan data dilakukan dengan menggunakan pendekatan observasi, wawancara dan studi literature untuk memperoleh data faktor-faktor penghambat dan penunjang dalam pengelolaan pengembangan Obyek Wisata Danau Matano.

\section{HASIL DAN PEMBAHASAN}

Pemerintah Daerah

Dari hasil wawancara yang dilakukan terhadap Pemerintah Daerah Kabupaten Luwu Timur terhadap tiga istansi pemerintah yang terkait dengan kawasan wisata Danau Matano yaitu Dinas Pariwisata, Dinas Kehutanan, dan Dinas Pendapatan Daerah dihasilkan sebagai berikut :

Dinas Pariwisata

Hasil wawancara terhadap salah satu informan kunci Dinas Pariwisata menyatakan bahwa sejauh ini prospek pengembangan pariwisata di Danau Matano belum maksimal dilakukan. Hal tersebut terjadi karena Kabupaten Luwu Timur memang pada dasarnya bukan merupakan daerah tujuan wisata, sehingga Pemerintah Daerah sejauh ini fokus pada program pembangunan daerah sehingga program prospek pengembangan pariwisata Danau Matano blum maksimal dilakukan. Selain itu, tingkat keinginan masyarakat Luwu Timur untuk berwisata masih sangat rendah, sehingga aktifitas wisata di kawasan Danau Matano jarang dilakukan.

Dinas Kehutanan

Hasil wawancara yang dilakukan di DInas Kehutanan Luwu Timur dihasilkan data bahwa sejauh ini telah banyak kegiatan-kegiatan baik berupa perlombaan maupun sosialisasi pembersihan kawasan Danau Matano yang dilakukan atas kerjasama Pemerintah Daerah dan ikatan Pemuda Luwu Timur. Pelibatan langsung pemuda Luwu Timur merupakan salah satu bukti kepedulian masyarakat akan kelestarian Danau Matano.

Dinas Pendapatan Daerah

Hasil wawancara yang dilakukan pada salah satu informan kunci Dinas Pendapatan Daerah menyatakan bahwa kendala yang selama ini 
mengakibatkan kawasan wisata Danau Matano masih kurang pengunjung adalah tingkat kesulitan untuk menjangkau kawasan Danau Matano, dimana aksesibilitas untuk mencapai kawasan wisata masih sangat minim, selain itu dia juga menyatakan bahwa selama ini banyak ditemukan warga Negara asing yang sengaja datang ke kawasan Danau Matano untuk meneliti keanekaragaman hayati di dalamnya, namun sayangnya penelitian yang mereka lakukan terkadang tidak resmi atau illegal. Tidak hanya itu maraknya penjualan jenis ikan botini yang merupakan salah satu ikan endemik Danau Matano yang dilakukan warga sekitar kawasan juga pernah ditemukan, hal ini terjadi karena kurangnya pemahaman masyarakat sekitar akan pentingnya menjaga kelestarian jenis ikan botini agar tidak punah.

\section{Balai Konservasi Sumber Daya Alam (BKSDA)}

Dari hasil wawancara yang telah dilakukan terhadap pihak Konservasi Sumber Daya Alam (KSDA) dihasilkan data bahwa untuk pengelolahan kawasan konservasi Danau Matano belum maksimal dilakukan oleh pihak pengelola, dikarenakan dalam hal pengambilan kebijakan pihak-pihak terkait kurang memahami prosedur atau langkah-langkah yang harus mereka lalui berdasarkan status kawasan, sehingga dalam pengelolaannya masih ditemukan kendala-kendala yang dapat mempengaruhi pengembangan Danau Matano kedepannya.

Pemerintah Daerah

Berdasarkan hasil wawancara yang telah dilakukan pada tiga istansi terkait yaitu Dinas Pariwisata, Dinas Kehutanan, dan Dinas Pendapatan Daerah Luwu Timur menyatakan siap bekerjasama dengan pihak pengelola dan masyarakat untuk mengembangkan potensi wisata Danau Matano.

Balai Konservasi Sumber Daya Alam (BKSDA)

Pada wawancara langsung yang dilakukan kepada Kepala Seksi Konservasi Sumber Daya Alam Malili Kabupaten Luwu Timur sebagai seksi pengelola kawasan Konservasi Danau
Matano dihasilkan data bahwa pihak pengelola siap bekerjasama dengan masyarakat dan Pemerintah Daerah untuk mengembangkan pariwisata Danau Matano namun perlu dilakukannya kesepakatan terlebih dahulu dalam hal pengambilan kebijakan dalam pengelolaan berdasaran ketentuan yang telah ditetapkan dalam undang-undang.

\section{Faktor Internal : Kekuatan (Strenght)}

Kawasan Danau Matano memiliki potensi wisata.

Kawasan Danau Matano sangat potensial untuk dikembangkan. Potensi tersebut meliputi kondisi bintang alam pada kawasan ini yang memiliki keindahan panorama alam, udara yang sejuk, dan kejernian air. Beberapa tempat di kawasan ini memiliki obyek daya tarik seperti potensi fisik berupa Pantai Ide, Pantai Kupukupu, sumber mata air, gua bawah air, kedalaman danau, kejernian air danau, Pulau Kembar, jenis ikan endemik Botini maupun budaya masyarakat sekitar kawasan yaitu "maopudi" atau mencari ikan di perairan Danau Matano, bercocok tanam di sekeliling kawasan Danau Matano. Akan tetapi potensi yang dimiliki harus ditangani dengan baik dan hati-hati khususnya dari sisi pemanfaatan secara lestari agar dampak dari kegiatan wisata ini tidak merusak kelestarian alam.

Lokasi yang mudah dijangkau.

Danau Matano memiliki lokasi yang tergolong strategis, karena kawasan ini terletak di sekitar Kota Sorowako. Seperti yang telah dijelaskan sebelumnya kawasan Danau Matano mudah untuk dijangkau dengan kendaraan roda empat, dan roda dua sehingga memudahkan pihak pengelola untuk terjun langsung ke lapangan.Ini menjadi salah satu kekuatan dalam pengelolaan kawasan Danau Matano dalam prospek pengembangan pariwisatanya karena dapat diketahui secara langsung oleh pengelola potensi-potensi yang dapat dikembangkan dan factor-faktor yang menjadi hambatan dalam kegiatan ini.

Faktor Internal : Kelemahan (Weakness) 
Akomodasi, Fasilitas, Sarana dan Prasarana yang kurang memadai.

Pengembangan pariwisata Danau Matano saat ini masih perlu memperhatikan hal-hal yang perlu dibenahi dari kawasan.Utamanya faktor-faktor yang dapat menunjang kegiatan pengembangan pariwisata. Berdasarkan hasil observasi yang telah dilakukan, sampai saat ini yang tersedia pada kawasan Danau Matano yaitu penginapan, rumah makan, MCK, perahu gayung (kayak), ban renang, peralatan renang, lapangan parkir, gazebo, jembatan, tempat sampah, dan warung-warung kecil yang telah disediakan. Kondisi tersebut menunjukkan bahwa faktor penunjang kegiatan berwisata pada kawasan ini masih minim, sehingga dalam pengembangannya masih banyak lagi yang perlu disediakan seperti mushollah, papan informasi, tempat penjualan souvenir all about Soroako or Matano lake, pos penjagaan (baik security maupun penjaga danau) dan lain-lain.

Pemanfaatan potensi wisata alam belum optimal.

Dalam hal pemanfaatan potensi wisata alam sejauh ini masih kurang optimaldisebabkan kurangnya promosi dan informasi potensi pariwisata alam yang dimiliki sehingga keadaan wisata serta potensi-potensi yang dimiliki Danau Matano masih kurang diketahui khalayak.Jika dibandingkan dengan Taman Wisata Alam Lejja yang terletak di Kab.Soppeng Propinsi Sulawesi Selatan jumlah pengunjung tiap tahunnya berkisar 103.634 sampai 168.887 orang pengunjung. Sedangkan jumlah pengunjung kawasan wisata Danau Matano berkisar 5 sampai 6 orang pengunjung saja (di luar libur hari raya). Maka untuk mengantisipasi hal tersebut, sebaiknya dilakukan promosi dan informasi mengenai potensi dan keadaan alam Danau Matano agar lebih dikenal khalayak.

Faktor Eksternal : Peluang (Opportunities)

Masyarakat bersedia berpartisipasi dalam pengembangan pariwisata.
Pelibatan masyarakat dalam pengelolaan kawasan ini akan menciptakan lapangan pekerjaan bagi masyarakat yang tentunya akan berdampak positif pada kesejahteraan masyarakat setempat sehingga mereka tidak perlu lagi hidup bergabung pada PT. Vale. Pemikiran seperti inilah yang membuat timbulnya keinginan dari masyarakat untuk berpartisipasi serta ikut menjaga dan melestarikan kawasan. Berdasarkan hasil wawancara diperoleh data partisipasi masyarakat dalam pengembangan pariwisata yaitu sebanyak $72 \%$ bersedia dan $28 \%$ yang tidak bersedia.

Gambar 1. Partisipasi Responden (Sumber

\begin{tabular}{|c|c|c|c|c|c|}
\hline \multirow[t]{2}{*}{ NO. } & \multirow{2}{*}{ Responden } & \multicolumn{2}{|c|}{$\begin{array}{c}\text { Warga } \\
\text { Masyarakat } \\
\text { Sekitar }\end{array}$} & \multicolumn{2}{|c|}{ Pedagang } \\
\hline & & Ya & Tidak & Ya & Tidak \\
\hline 1. & $\begin{array}{l}\text { Partisipasi } \\
\text { masyarakat } \\
\text { dalam } \\
\text { pengembanga } \\
\text { nkan } \\
\text { pariwisata }\end{array}$ & 72 & 28 & 24 & 0 \\
\hline 2. & $\begin{array}{l}\text { Pengetahuan } \\
\text { lokasi } \\
\text { potensial }\end{array}$ & 51 & 39 & 9 & 12 \\
\hline
\end{tabular}

BKSDA)

Sebanyak 72 responden warga masyarakat sekitar bersedia berpartisipasi dan seluruh pedagang bersediah berpartisipasi. Ini merupakan salah satu modal utama dalam pengembangan pariwisata, karena dengan berpartisipasinya masyarakat dan pedagang di sekitar kawasan, maka akan mempermudah dan mempercepat proses pengembangan pariwisata Danau Matano. Selain bersedia untuk membantu dalam pelaksanaan kegiatan, partisipasi masyarakat juga dapat dilihat dari pengetahuan masyarakat tentang lokasi-lokasi obyek wisata yang berada di dalam kawasan, pada umumnya masyarakat yang sering melakukan aktifitas di dalam kawasan mengetahui tempat-tempat 
yang sangat potensial untuk dikembangkan. Sebanyak 51 orang responden warga masyarakat sekitar mengetahui lokasi-lokasi wisata yang ada dalam kawasan dan sisanya 49 orang responden tidak mengetahui lokasilokasi, sedangkan dari masyarakat yang berprofesi sebagai pedagang sebanyak 9 orang mengetahui lokasi-lokasi potensial dan selebihnya 12 orang tidak mengetahui. Tingginya tingkat pengetahuan masyarakat tentang kawasan Danau Matano menjadi modal dasar untuk berpartisipasi karena informasi dari masyarakat sangat penting dalam pengelolaan peningkatan kualitas pariwisata di Danau Matano.

Pihak Pemerintah Daerah dan pihak Pengelola Balai Konservasi Sumber Daya Alam (BKSDA) siap untuk bekerja dalam peningkatan pariwisata Danau Matano.

Berdasarkan hasil wawancara yang telah dilakukan, dalam hal prospek pengembangan pariwisata Danau Matano, Pemerintah Daerah beserta pihak pengelola dari BKSDA bersedia dan siap bekerja demi tercaoainya tujuan dengan baik dan optimal. Dengan semangat dan tekad pemerintah daerah dengan pihak pengelola, ini merupakan modal dasar serta merupakan peluang mempermudah jalannya program kegiatan dalam meningkatkan pariwisata Danau Matano menjadi kawasan wisata yang lebih dikenal oleh khalayak.

\section{Faktor Eksternal : Ancaman (Threats)}

Sebagai objek wisata alam terdapat di sekitar wilayah PT. Vale.

Lokasi Danau Matano berada disekitar kawasan tambang PT. Vale sehingga masyarakat dan beberapa karyawan PT. Vale beranggapan bahwa Danau Matano merupaka milik PT. Vale. Berdasarkan hasil wawancara yang dilakukan terhadap masyarakat sekitar Danau Matano, masyarakat menganggap bahwa Danau Matano sebagai lokasi wisata karena dikelola dan dikembangkan oleh PT. Vale. Hal ini mengakibatkan pengusaha pariwisata alam yang ingin berinvestasi terhambat.Ini merupakan ancaman baik bagi pihak pengelola maupun Pemerintah Daerah dalm hal pengelolaannya kedepan. Maka dari itu perlunya dilakukan koordinasi antara Balai Konservasi Sumber Daya Alam, Pemerintah Daerah Luwu Timur dan PT. Vale dalam pengembangan pariwisata Danau Matano selanjutnya.

Belum singkronnya peraturan yang dikeluarkan Pemerintah Daerah dan pihak pengelola.

Danau Matano merupakan kawasan konservasi yang dibeberapa lokasinya telah dilakukan pembangunan, baik dari pihak PT. Vale maupun masyarakat setempat. Tempat penyewaan alat renang dan perahu gayung (kayak) yang merupakan bangunan beton berada di tepi Danau Matano dengan menggunakan lahan yang masih merupakan kawasan konservasi dan dianggap merusak kawasan serta kelestariannya. Hal ini terjadi karena pemberian kebijakan izin pembangunan tersebut tidak melalui pihak pengelola kawasan Danau Matano yaitu BKSDA melainkan melalui Pemerintah Daerah.Ini merupakan ancaman kelestarian bagi Danau Matano kedepan.

Pemanfaatan areal oleh masyarakat yang tidak sesuai peruntukannya.

Pada lokasi perairan Danau Matano tepatnya di desa Tambeha dan area Sorowako Lama, terdapat beberapa rumah penduduk berdiri kokoh, berdasarkan penelitian yang telah dilakukan, masyarakat memanfaatkan daerah perairan Danau Matano yang masih terbilang dangkal sebagai lahan pemukiman. Dampak yang ditimbulkan dengan dijadikannya daerah perairan Danau Matano sebagai lokasi pemukiman, sampah-sampah berserakan, limbah manusia dimana-mana hingga mengotori air Danau Matano

Ketertarikan masyarakat terhadap kegiatan wisata alam masih rendah

Sejauh ini minat masyarakat Kabupaten Luwu Timur terhadap pentingnya berwisata masih rendah.Ini disebabkan karena sebagian 
besar penduduk setempat berprofesi sebagai petani selebihnya karyawan PT. Vale dan Pegawai Negeri Sipil. Dalam kehidupan seharihari masyarakat banyak melakukan aktifitasnya di alam terbuka, selain itu masyarakat yang berprofesi sebagai karyawan PT. Vale bermukim di sekitar kawasan Danau Matano. Hal-hal tersebut merupakan dampak dari rendahnya kontribusi kunjungan wisata alam masyarakat setempat, sehingga masih perlu dilakukan sosialisasi dengan tujuan perlahan merubah pola pikir masyarakat agar lebih peduli terhadap daerah wisata Danau Matano yang selanjutnya meningkatkan minat berwisata.

a. Strategi Pengembangan Pariwisata Danau Matano

Secara operasional diperlukan suatu strategi implementasi guna memudahkan perwujudan kebijakan pengelolaan pariwisata Danau Matano. Analisis SWOT digunakan untuk menentukan strategi prospek pengembangan pariwisata dengan melihat kombinasi faktor internal dan faktor eksternal .Kedua faktor tersebut memberikan dampak positif yang berasal dari kekuatan (strengths) dan peluang (opportunities), sedangkan dampak negatif yang berasal dari kelemahan (weakness) dan ancaman (threats). Strategi yang dirumuskan dapat dilihat pada Gambar 1

\begin{tabular}{|c|c|c|}
\hline \multirow[b]{2}{*}{ Eksternal } & Kekuaatn (S) & Kelemahan (W) \\
\hline & $\begin{array}{l}\text { a. Kawasan Danau } \\
\text { Matano memiliki } \\
\text { potensi wisata. } \\
\text { b. Lokasi yang mudah } \\
\text { dijangkau }\end{array}$ & $\begin{array}{l}\text { a. Akomodasi, fasilitas, } \\
\text { sarana dan prasarana } \\
\text { kurang memadai } \\
\text { b. Pemanfaatan potensi } \\
\text { wisata alam belum } \\
\text { optimal }\end{array}$ \\
\hline Peluang (0) & Strategi (SO) & Strategi (WO) \\
\hline $\begin{array}{ll}\text { a. } & \begin{array}{l}\text { Masyarakat bersedia } \\
\text { berpartisipasi dalam }\end{array} \\
\text { pengembangan } \\
\text { pariwisata } \\
\text { b. Pihak Pemerintah Daerah } \\
\text { dan pikah Balai } \\
\text { Konservasi Sumber Daya } \\
\text { Alam siap untuk bekerja } \\
\text { dalam peningkatan } \\
\text { pariwisata Danau Matano }\end{array}$ & $\begin{array}{l}\text { a. Pengembangan } \\
\text { program pariwisata } \\
\text { berbasis masyarakat. } \\
\text { b. Penataan potensi } \\
\text { wisata alam }\end{array}$ & $\begin{array}{l}\text { Melakukan promosi dan } \\
\text { informasi potensi wisata } \\
\text { alam }\end{array}$ \\
\hline Ancaman (T) & Strategi (ST) & Strategi (WT) \\
\hline
\end{tabular}




\begin{tabular}{|c|c|c|}
\hline 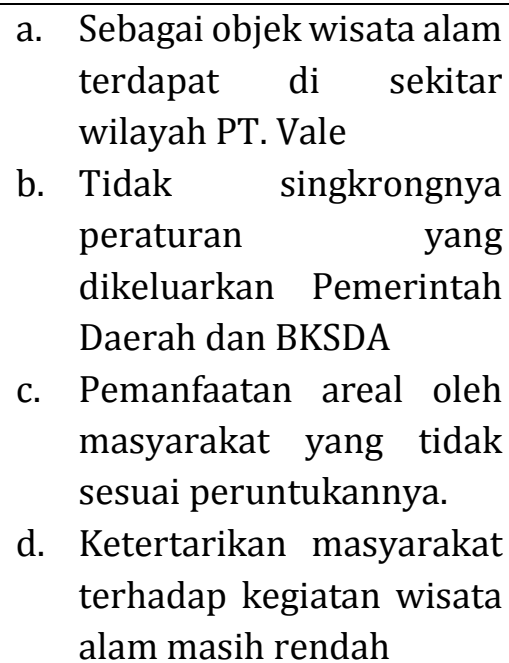 & $\begin{array}{l}\text { a. Peningkatan peran } \\
\text { aktif pengelola } \\
\text { b. Menjalin kerja sama } \\
\text { antara semua pihak } \\
\text { dalam pengelolaan } \\
\text { kawasa }\end{array}$ & $\begin{array}{l}\text { a. Melengkapi fasilitas, } \\
\text { sarana dan prasarana } \\
\text { b. Melakukan sosialisasi } \\
\text { terhadap masyarakat } \\
\text { dan stake holder }\end{array}$ \\
\hline
\end{tabular}

\section{PEMBAHASAN}

Setelah dilakukan penelitian dan pengelolaan data Analisis SWOT untuk Prospek Pengembangan Pariwisata Danau Matano :

\section{Faktor Internal di Danau Matano}

Kekuatan (Strength)Yaitu, Danau Matano memiliki potensi pariwisata seperti keberadaan ikan endemic, Pantai Ide, Pantai Kupu-Kupu, Pantai C (Salonsa), Pantai Impian, sumber mata air danau, sungai dingin, Pulau Kembar, Gua darat dan bawah air dan kejernian air danau, serta lokasi yang mudah dijangkau.

Kelemahan (Weakness) yaitu, Akomodasi, fasilitas, sarana, prasarana kurang memadai dan pemanfaatan potensi wisata alam yang belum optimal.

Faktor Eksternal di Danau Matano

Peluang(Opportunities)

Yaitu, Masyarakat bersedia berpartisipasi dalam pengembangan pariwisata dan pihak Pemerintah Daerah serta pihak pengelola BKSDA siap untuk bekerja dalam prospek pengembangan pariwisata Danau Matano.

Ancaman(Threats)

Yaitu, Sebagai objek wisata alam terdapat di sekitar wilayah PT. Vale, tidak singkronnya peraturan yang dikeluarkan pihak Pemerintah Daerah dan BKSDA, perambahan berupa pemanfaatan areal oleh masyarakat yang tidak sesuai peruntukannya, dan ketertarikan masyarakat terhadap kegiatan wisata alam yang

\section{KESIMPULAN}

Faktor Internal di DanauMatano
Kekuatan (Strength)

Yaitu Danau Matano memiliki potensi pariwisata seperti keberadaan ikan endemic, Pantai Ide , Pantai Kupu-Kupu, Pantai C (Salonsa), Pantai Impian, sumber mata air danau, sungai dingin, Pulau Kembar, Gua darat dan bawah air dan kejernian air danau, serta lokasi yang mudah dijangkau.

Kelemahan (Weakness)

Yaitu Akomodasi, fasilitas, sarana, prasarana kurang memadai dan pemanfaatan potensi wisata alam yang belum optimal.

Faktor Eksternal di Danau Matano a) Peluang (Opportunities) yaitu Masyarakat bersedia berpartisipasi dalam pengembangan pariwisata dan pihak Pemerintah Daerah serta pihak pengelola BKSDA siap untuk bekerja dalam prospek pengembangan pariwisata Danau Matano b) Ancaman(Threats) yaitu Sebagai objek wisata alam terdapat di sekitar wilayah PT. Vale, tidak singkronnya peraturan yang dikeluarkan pihak Pemerintah Daerah dan BKSDA, perambahan berupa pemanfaatan areal oleh masyarakat yang tidak sesuai peruntukannya, dan ketertarikan masyarakat terhadap kegiatan wisata alam yang masih rendah. c) Strategi pengembangan kawasan wisata Danau Matano yang dihasilkan prospek pengembangan program pariwisata berbasis masyarakat, mengembangkan potensi wisata alam, melakukan promosi dan informasi potensi wisata alam, meningkatan peranaktif pengelola, menjalin kerjasama antara semua pihak dalam pengelolaan kawasan, merekomendasikan PT. 
Vale bekerja sama membangun dan melengkapi fasilitas, sarana dan prasarana, melakukan sosialisasi terhadap masyarakat dan stakeholder.

\section{DAFTAR PUSTAKA}

Anak Agung Putri Sari, 2013. Faktor-Faktor Yang Memotivasi Perempuan Sebagai

Pengelola Pondok Wisata di Kelurahan Ubud, Kecamatan Ubud, Kabupaten Gianyar.

Anestiya Pramesti. 2012. Prospek Dan Upaya Pengembangan Pariwisata Cavetubing Gua Pindul. Provinsi Daerah Istimewah Yogyakarta

Angga Pradikta. 2013. Strategi Pengembangan Obyek Wisata Waduk Gunung rowo Indah Dalam Upaya Meningkatkan Pendapatan Asli Daerah (PAD) Kabupaten Pati

Anonymous. (1993). Pengertian Wisata Badan Pengendalian Dampak Lingkungan, 2001. Pengembangan Ekowisata Indonesia dalam rangka pengendalian kerusakan keanekaragaman hayati di Taman Nasional dan Taman Wisata Alam. Direktorat Jendral Pengendalian Kerusakan, Kenakeragama Hayat

Dinas Pendidikan, Kebudayaan, Pariwisata, Pemuda dan Olahraga Kab. Luwu Timur. 2011. Mengenal Potensi Budaya \& Pariwisata Luwu Timur. Luwu Timur.

Dinas Pendidikan, Kebudayaan, Pariwisata, Pemuda dan Olahraga Kabupaten Luwu Timur.

Kartini La Ode Unga, I Made Benyamin, Ronald Alexander Barkey, 2011. Strategi

Pengembangan Kawasan Wisata Kepulauan Banda

Kementrian Negara Lingkungan Hidup, 2008. Pedoman Pengelola Ekosistem Danau. Penerbit : Kementrian Negara Lingkungan Hidup RI

Kristian Suhartadi Widi Nugrah, 2012. Strategi Pengembangan Wisata Agro Wonosari.

Lituhayu, Heri. 2011. Strategi Pengembangan

Pemasaran Daerah Tujuan Wisata.

Jakarta : Balai Pustaka
Meydrikson Hiborang, 2005. Strategi

Pengeloaan Pariwisata Oleh Dinas Kebudayaan dan Pariwisata Kabupaten Kepulauan Sitaro.

Misbakhul Munir Zain, Dr. Ir. Muhammad Taufik 2011. Pengembangan Potensi Wisata Alam Kabupaten Tulungagung Dengan Sistem Informasi Geografis.

Nining Yuningsih, 2005 . Peningkatan Pendapatan Asli Daerag (PAD) Melalui Pengembangan Potensi Obyek Wisata Pantai Pangandaran di Kabupaten Ciamis Jawa Barat

Richard A de Fretes, Purnomo B Santoso, Rudy Soenoko, Murty Astuti, 2013. Strategi Perencanaan dan Pengembangan Industri Pariwisata Dengan Menggunakan Metode SWOT dan QSMP (Studi Kasus Kecamatan Leitumur Selatan Kota Ambon)

Sammeng, Andi Mappi. 2011. Cakrawala Pariwisata. Jakarta : Balai Pustaka.

Setianingsih, Wahyu. 2005. Pengembangan Obyek Wisata Serulingmas Sebagai Salah Satu Sumber Pendapatan Asli Daerah Kabupaten Banjarnegara. Skripsi Universitas Negeri Semarang.Sefira Ryalita Primadany, Mardiyono, Riyanto, 2013. Analisis Strategi Pengembangan Pariwisata Daerah

Soebagyo, 2012. Strategi Pengembangan Pariwisata Di Indonesia

Suparmoko. 2002. Ekonomi Publik : Untuk Keuangan \& Pembangunan Daerah. Yogyakarta : ANDI

Suwanto, G.2004. Dasar-Dasar Pariwisata. Yogyakarta

Yoeti, 2008. Perencanaan dan Pengembangan Pariwisata. Jakarta : PT Pradnya Paramita. 